\title{
Evoked Response Audiometry according to gender and age: findings and usefulness
}

\author{
Edmir Américo Lourenço ${ }^{1}$, Marcelo Henrique de \\ Oliveira $^{2}$, Adriana Umemura ${ }^{3}$, Ana Laura Vargas \\ ${ }^{4}$, Karen de Carvalbo Lopes ${ }^{5}$, Álvaro Vitorino de \\ Pontes Júnior ${ }^{6}$
}

Keywords: findings, evoked response audiometry, age and gender distribution, auditory evoked potentials.

\section{Summary}

\begin{abstract}
A
uditory evoked brainstem responses (ABR) is a noninvasive electrical potential registration which evaluates the auditory tract from the middle ear to the auditory cortex in the first 12 milliseconds (ms). The ABR is an important otoneurological evaluation. Aim: confirm the test's usefulness, major incidence and topography according to are range gender considering the absolute latencies of the waves and interpeak intervals. Materials and Method: we retrospectively analyzed 403 tests from a private clinic in the city of Jundiaí-São Paulo State-Brazil, from patients suspected of auditory damage or central nervous disorder, and the patients were broken down according to gender and age. Results and Conclusions: ABR is an important test to determinate the soundness of the auditory tract, the electrophysiological thresholds and topodiagnosis. We found no differences between type of loss and gender; there was a major incidence of retrocochlear findings among male patients between 12-20 years old; children under one year with risk factors did not present higher incidences of auditory findings when compared with all the population analyzed. The absolute latencies of waves I, III and V were higher in males, but the interpeak intervals were similar in both genders, showing that interval I-III was more frequently altered.
\end{abstract}

\footnotetext{
${ }^{1}$ MSc in ENT-HNS and PhD in Medicine - UNIFESP, Adjunct Professor, Head of the ENT Program - FMJ.

${ }^{2}$ MD. Former ENT resident - Faculdade de Medicina de Jundiaí (FMJ) - SP, ENT working in Belo Horizonte-MG.

${ }^{3}$ MD. Former ENT resident - Faculdade de Medicina de Jundiaí (FMJ) - SP, ENT working in Jundiaí.

${ }^{4}$ MD. Former ENT resident - Faculdade de Medicina de Jundiaí (FMJ) - SP, ENT working in Itu-SP.

${ }^{5}$ MD. Former ENT resident - Faculdade de Medicina de Jundiaí (FMJ) - SP, ENT working in Jundiaí at ATEAL- Assoc. Terap. Estim. Auditiva e Linguagem.

${ }^{6}$ MD. Former ENT resident - Faculdade de Medicina de Jundiaí (FMJ) - SP, ENT working in Jundiaí na ATEAL - Assoc. Terap. Estimul. Audit. e Linguagem. Faculdade de Medicina de Jundiaí - SP.

Send correspondence to: Edmir Américo Lourenço - Rua do Retiro 424 5o andar conjuntos 53 e 54 B Anhangabaú Jundiaí SP $13209-000$. Tel. (0xx11) 4521-1697; (0xx11) 4521-3181.

This paper was submitted to the RBORL-SGP (Publishing Manager System) on 12 February 2007. Code 3669. The article was accepted on 22 July 2007.
} 


\section{INTRODUCTION}

Every sensorineural structure, when submitted to a stimulus, emits bioelectrical potentials as response. Thus, the acoustic stimulation of the human auditory receptor triggers a number of electrical responses, or evoked potentials, which result in the successive activation of the cochlea and the neurons which make up the auditory pathway. ${ }^{1}$

The technical capacity to record electrical potentials in different levels of the nervous system in response to acoustic stimulation has produced a large number of relevant applications to otolaryngologists, audiologists and neurologists. These potentials may be recorded by non-invasive techniques, without bringing discomfort to the patient, and often without the need for sedation or anesthesia, which has increased its clinical applicability. ${ }^{2}$ Auditory Evoked Potentials (AEP) enable the assessment of the auditory pathway functional integrity, from the peripheral receptor organ, all the way to the cerebral cortex.

There are many expressions found in the literature, such as Brain Stem Audiometry - BERA (Brainstem Evoked Responses Audiometry), very much used in Brazil, and also the less proper expressions and which are farther apart from its properties.

ABR (Audiometry Brainstem Responses) is based on the recording and analysis of the electrophysiological activity of the peripheral auditory system all the way to the brain stem. These are early auditory evoked potentials, because the responses arise in the first 12 milliseconds (ms) after sound stimuli and it is made up of a seven wave polyphasic potential. ${ }^{2}$ Waves I, III and $\mathrm{V}$ are the most prominent, and for this reason these are the waves considered in the analysis of the plotted graph. The parameters assessed are: the very presence of the waves, replication or reproducibility, absolute latency, latency interval between waves (interpeak intervals), interaural latency difference, sound intensity, latency and amplitude. ${ }^{3}$

AEPs, besides enabling one to investigate the individual's peripheral hearing, they also help assess the central auditory pathway integrity, its maintenance during the development process and dysfunctions caused by many diseases. ${ }^{4}$

ABR's clinical applications can be divided into neurologic and audiologic, with the main goal of identifying abnormalities in the auditory nerve and the brain stem, and estimate the electrophysiological auditory threshold, based on the presence of responses to different levels of stimulus intensity. In the literature we find papers that use $\mathrm{ABR}$ as an auditory screening test for high risk newborns., ${ }^{5,6}$ It is also used for intraoperative monitoring during ponscerebellar angle surgery. ${ }^{7}$ One of the most studied applications of this type of test is to diagnose vestibular nerve schwannomas ${ }^{3}$; however, there are controversies regarding the test's sensitivity and specificity. ${ }^{8}$
Today, ABR is very important in otoneurological assessments, and it is used by many medical specialties because of its high sensitivity, speed, objectivity and also because it enables one to follow disease progression and that of treatment.

Our goal with the present investigation is to analyze and compare ABR traces in regards to: gender distribution; test applicability to the different age ranges; risk factors correlation in newborns up to one year of age and test alterations; incidence of conductive/cochlear alterations; retrocochlear alterations; increase in wave absolute latency and interpeak interval alterations, including a differential study of these parameters in so far as gender is concerned.

\section{MATERIALS AND METHODS}

We carried out a retrospective study, properly approved by the Ethics in Research Committee (CEP) of the Faculdade de Medicina de Jundiaí (FMJ) - SP, in a population of 403 patients who were referred to us by pediatricians, neuro-pediatricians, neurologists, neurosurgeons and otorhinolaryngologists, with doubts regarding their hearing and/or alterations in the central auditory pathways (retrocochlear), submitted to the brainstem audiometry test (ABR) in a private clinic of Jundiaí, in the State of São Paulo. The tests were carried out from June of 1998 to May of 2005 and sequentially analyzed, not excluding any chart. We used a GSI ${ }^{\circledR}-55$ ABR Screener device, at 2000 clicks

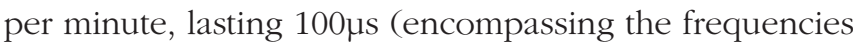
from 2000 to $4000 \mathrm{~Hz}$ ), with one channel insertion phones and a 12 millisecond window. The sample was initially broken down by gender. The patients were broken down by age range (less than one year, between one year and less than 6 years, between 6 years and less than 12 years, between twelve years and less than 20 years, between 20 years and less than forty years, between forty years and less than 70 years, and finally, those with more than 70 years of age. As far as applicability is concerned, the tests were plotted in accordance to their end or indication (hearing threshold, retrocochlear assessment or both). As conductive and/or cochlear alterations we considered: absolute latency increase of all the waves without interpeak interval alterations and a lowering of the minimum response level. As for retrocochlear alteration, we considered an increase in wave absolute latency time and/or wave amplitude alteration. Following that, we assessed: the distribution of conductive/cochlear and retrocochlear findings, in agreement with gender and age range, absolute latencies associated with gender and the incidence of alterations in interpeak intervals. In children younger than twelve years of age and in the presence of risk factors we analyzed the incidence of conductive, cochlear and retrocochlear alterations, in accordance with the aforementioned criteria. The neonatal risk factors considered in our paper were 
the same ones described in the 2000 consensus from the "Joint Committee on Infant Hearing" (which include the American Academies of Audiology, Otolaryngology and Head and Neck Surgery, Pediatrics, Speech, Language and Hearing and the Education Council for the Hearing Impaired), to say:

1) less than 1500 grams of birth weight or preterm less than 34 weeks;

2) newborn small for the gestational age;

3) severe Perinatal asphyxia;

4) intracranial hemorrhage or leucoencephalomalacia;

5) suspected or confirmed congenital infection;

6) bacterial meningitis and/or septicemia;

7) use of ototoxic drugs;

8) hyperbilirubinemia;

9) family history of hearing loss;

10) parents who are related;

11) syndromes associated with hearing loss;

12) head and neck malformations;

13) Newborns who required neonatal ICU for 48 hours or more. All the data collected was stored in a database created in Access ${ }^{\circledR}$ and was later on analyzed and plotted in tables and charts.

\section{RESULTS}

Table 1. Population studied broken down by gender.

\begin{tabular}{cccc}
\hline Gender & Females & Males & Total \\
\hline $\mathrm{n}$ & 173 & 230 & 403 \\
\hline
\end{tabular}

Table 2. Distribution of the population studied by age.

\begin{tabular}{|c|c|}
\hline Age (years) & $n$ \\
\hline $0 \mathrm{l}-\mathrm{-} 1$ & 58 \\
\hline 1 I-- 6 & 132 \\
\hline $6 \mid-12$ & 15 \\
\hline 12 I-- 20 & 14 \\
\hline 20 l-- 40 & 67 \\
\hline 40 I-- 70 & 107 \\
\hline 70 I-- & 10 \\
\hline Total & 403 \\
\hline
\end{tabular}

Table 3. Reason for ordering the test (ABR), distributed by age range.

\begin{tabular}{lcccc}
\hline Age (years) & $\begin{array}{c}\text { Reason } \\
\text { Hearing } \\
\text { threshold }\end{array}$ & $\begin{array}{c}\text { Brainstem } \\
\text { assess- } \\
\text { ment }\end{array}$ & both & Total \\
\hline 0 I-- 1 & 6 & 0 & 52 & 58 \\
1 I-- 6 & 11 & 5 & 115 & 132 \\
6 I-- 12 & 1 & 2 & 13 & 15 \\
12 I-- 20 & 0 & 9 & 5 & 14 \\
20 I-- 40 & 1 & 54 & 12 & 67 \\
40 I-- 70 & 0 & 85 & 22 & 107 \\
70 I-- & 0 & 8 & 2 & 10 \\
\hline Total & 19 & 163 & 221 & 403 \\
\hline
\end{tabular}

Table 4. Number of female patients with conductive or cochlear alterations.

\begin{tabular}{ccc}
\hline $\begin{array}{c}\text { Cochlear or conduc- } \\
\text { tive alteration }\end{array}$ & Other diagnosis & total \\
\hline 77 & 96 & 173 \\
\hline
\end{tabular}

Table 5. Incidence of male patients with conductive or cochlear hearing loss.

\begin{tabular}{ccc}
\hline $\begin{array}{c}\text { Cochlear or conduc- } \\
\text { tive alteration }\end{array}$ & Other diagnosis & total \\
\hline 106 & 124 & 230 \\
\hline
\end{tabular}

Table 6. Incidence of female patients with retrocochlear alterations.

\begin{tabular}{ccc}
\hline $\begin{array}{c}\text { Retrocochlear alte- } \\
\text { ration }\end{array}$ & Other diagnosis & total \\
\hline 31 & 142 & 173 \\
\hline
\end{tabular}

Table 7. Incidence of male patients with retrocochlear alterations..

\begin{tabular}{ccc}
\hline $\begin{array}{c}\text { Retrocochlear alte- } \\
\text { ration }\end{array}$ & Other diagnostics & total \\
\hline 49 & 181 & 230 \\
\hline
\end{tabular}


Table 8. Distribution of patients with conductive or cochlear hearing loss per age range in relation to other diagnostics.

\begin{tabular}{lcccc}
\hline Age & $\begin{array}{c}\text { Other diag- } \\
\text { nostics }\end{array}$ & $\begin{array}{c}\text { Con- } \\
\text { ductive/ } \\
\text { cochlear } \\
\text { alterations }\end{array}$ & Total & Index \\
\hline 0 I-- 1 & 39 & 19 & 58 & 0,33 \\
1 I-- 6 & 67 & 65 & 132 & 0,49 \\
6 I-- 12 & 4 & 11 & 15 & 0,73 \\
12 I-- 20 & 10 & 4 & 14 & 0,29 \\
20 I-- 40 & 36 & 31 & 67 & 0,46 \\
40 I-- 70 & 62 & 45 & 107 & 0,42 \\
70 I-- & 2 & 8 & 10 & 0,8 \\
\hline Total & 220 & 183 & 403 & 0,45 \\
\hline
\end{tabular}

Table 9. Distribution of the patients with retrocochlear alterations per age range in relation to other diagnosis $(n=403)$.

\begin{tabular}{lcccc}
\hline Age & $\begin{array}{c}\text { Other diag- } \\
\text { nosis }\end{array}$ & $\begin{array}{c}\text { Retrococh- } \\
\text { lear altera- } \\
\text { tions }\end{array}$ & Total & Index \\
\hline 0 I-1 & 45 & 13 & 58 & 0,22 \\
1 I-6 & 103 & 29 & 132 & 0,22 \\
6 I-12 & 14 & 1 & 15 & 0,07 \\
12 I-20 & 9 & 5 & 14 & 0,36 \\
20 I-40 & 58 & 9 & 67 & 0,13 \\
40 I-70 & 84 & 23 & 107 & 0,21 \\
70 I-- & 10 & 0 & 10 & 0 \\
\hline Total & 323 & 80 & 403 & 0,20 \\
\hline
\end{tabular}

Table 10. Increase in the absolute wave latency of the general population $(n=403)$.

\begin{tabular}{|c|c|c|c|c|c|c|c|}
\hline Gender & No increase & $\begin{array}{c}\text { Increase wave } \\
1\end{array}$ & $\begin{array}{c}\text { Increase wave } \\
3\end{array}$ & $\begin{array}{c}\text { Increase wave } \\
5\end{array}$ & $\begin{array}{c}\text { Increase in all } \\
\text { waves }\end{array}$ & No waves & Total \\
\hline$M$ & 108 & 9 & 7 & 18 & 72 & 33 & 247 \\
\hline $\mathrm{F}$ & 93 & 10 & 5 & 8 & 44 & 25 & 185 \\
\hline Total & 201 & 19 & 12 & 26 & 116 & 58 & $432^{*}$ \\
\hline
\end{tabular}

Table 11. Incidence of interpeak interval alterations broken down by gender. Males prevailed.

\begin{tabular}{ccccccccccc}
\hline Gender & $\begin{array}{c}\text { I-III unalte- } \\
\text { red }\end{array}$ & I-II altered & I-III absent & $\begin{array}{c}\text { III-V unal- } \\
\text { tered }\end{array}$ & $\begin{array}{c}\text { III-V alte- } \\
\text { red }\end{array}$ & $\begin{array}{c}\text { III-V ab- } \\
\text { sent }\end{array}$ & $\begin{array}{c}\text { I-V unalte- } \\
\text { red }\end{array}$ & I-V altered & I-V absent & Total \\
\hline F & 130 & 10 & 33 & 136 & 5 & 32 & 133 & 9 & 31 & 173 \\
M & 178 & 17 & 35 & 182 & 15 & 33 & 182 & 13 & 35 & 230 \\
Total & 308 & 27 & 68 & 318 & 20 & 65 & 315 & 22 & 66 & 403
\end{tabular}

\section{DISCUSSION}

Within the analyzed period, we carried out brain stem audiometry (ABR) in 403 patients, with a predominance of males (57\% - Table 1 and Graph 1).

As far as age is concerned, we observed two peaks of incidence:

1) age range between 1 and 6 years, having seen that in the pediatric population, classic tonal audiometry is more properly carried out within the mental ages of 5 and 7 years, and that is why we preferred the electrophysiological test;

2) age range between 40 and 70 years, since in it $\mathrm{ABR}$ is frequently used for the topodiagnosis of hearing loss or hearing complaints10 (Table 2 and Graph 2). Such fact is reinforced by Table 3 and Graph 3 which show a proper indication of $\mathrm{ABR}$ orders, in other words, in the pediatric range until 6 years, ABR prevailed in order to assess the auditory threshold in relation to the brain stem evaluation, while in adults the opposite happened. In the general distribution, 5\% (19) of the tests were ordered with the aim of checking the auditory threshold, $40 \%$ (163) for stem assessment and 55\% (221) for both.

By analyzing the Tables and Graphs 4 and 5, we noticed an incidence of conductive or cochlear alterations of $44.5 \%$ in females and of $46 \%$ in males, while the incidence of retrocochlear findings was of $17.9 \%$ in females and of $21.3 \%$ in males, the latter was statistically significant ( $p>0.05-$ Tables and Graphs 6 and 7).

By analyzing the conductive or cochlear alterations by age range, we noticed a higher incidence in the age range of 70 years with a rate of 0.80 (very likely because of a hearing loss associated with aging and degenerative alterations) ${ }^{11}$. The general index was 0.45 (Table 8 and Graph 8).

As far as retrocochlear alterations are concerned we see a higher incidence in the age range between 12 and 20 years $(n=14)$, with an index of 0.36 ; and a general index of 0.20 (Table 9 and Graph 9), and when we analyze those 
children below one year of age $(n=58)$ the incidence of conductive/cochlear and retrocochlear alterations, even with the risk factors reported in the Method, we noticed indices of 0.33 and 0.22 respectively. These values are near and one of them is even lower than the one found in the general sample $(n=403)$, which were 0.45 and 0.20 respectively. Thus, we noticed that children with risk factors did not show a higher incidence of conductive, cochlear or retrocochlear alterations when compared to the general population studied.

In relation to the absolute latencies of waves I, III and $\mathrm{V}$, we observed a difference between the genders, and they were higher among males, and this is in agreement with literature reports ${ }^{12}$ (Table 10 and Graph 10).

\section{Percentage distribution per gender $n=403$}

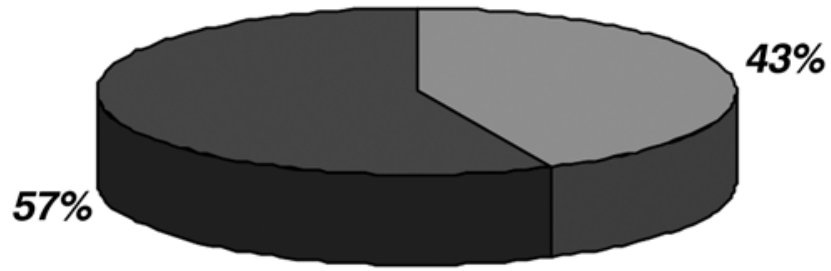

\section{$\square$ Female $\square$ Male}

Graph 1. Distribution of the population studied by gender.

\section{Distribution of the population studied according to age $n=403$}

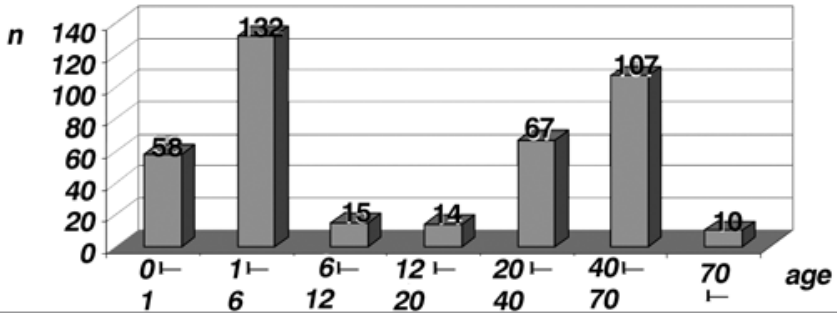

Graph 2. Distribution of the population studied by age, in years $(n=403)$.

In relation to interpeak interval alterations $(n=69)$, we noticed that there were no differences between the genders, and the I-III interval was the one that presented the higher rate of alterations (39\%)(Graph 11). Although the incidence of alterations in the interpeak intervals is higher for men (Table 11 and Graph 12), we highlight the greater incidence in males (230 men: 173 women studied) and small percentage differences. According to the literature, gender and age, the frequency of the stimulus and click phase impact on the absolute latencies, being however, controversial the influence of these factors in interpeak intervals ${ }^{12}$.

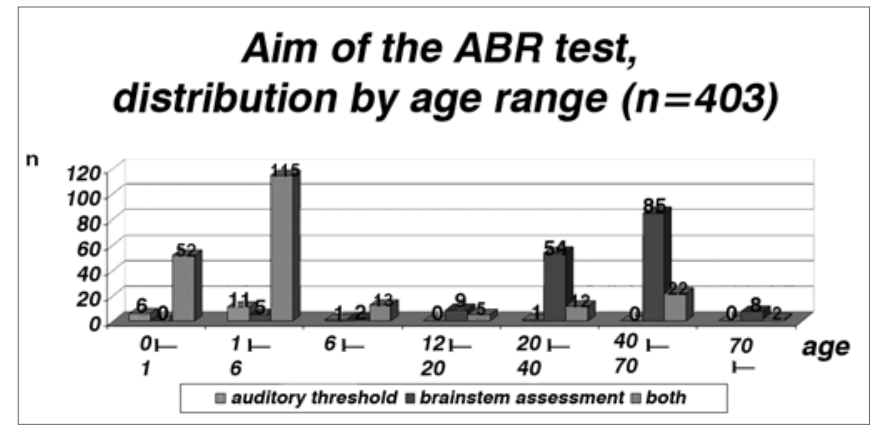

Graph 3. Reason for ordering the test (ABR), broken down by age range $(n=403)$.

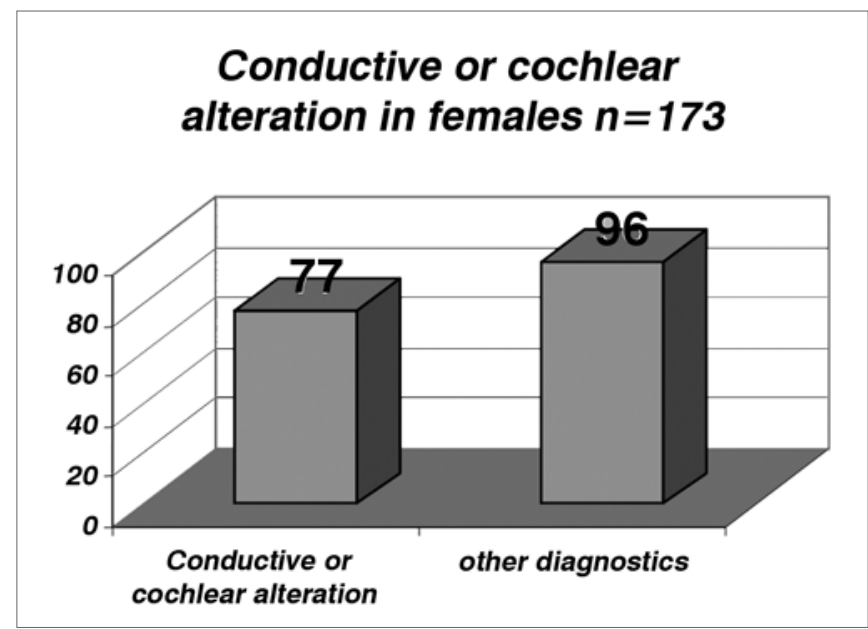

Graph 4. Incidence of female patients with conductive or cochlear alterations (index of 0.445 or $44.5 \%$ ).

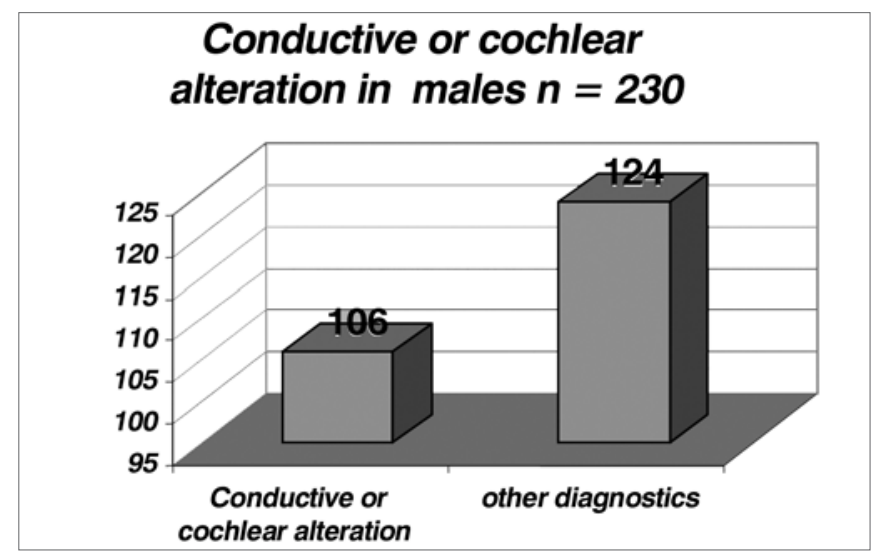

Graph 5. Incidence of male patients with conductive or cochlear alterations (index of 0.46 or $46 \%$ ). 


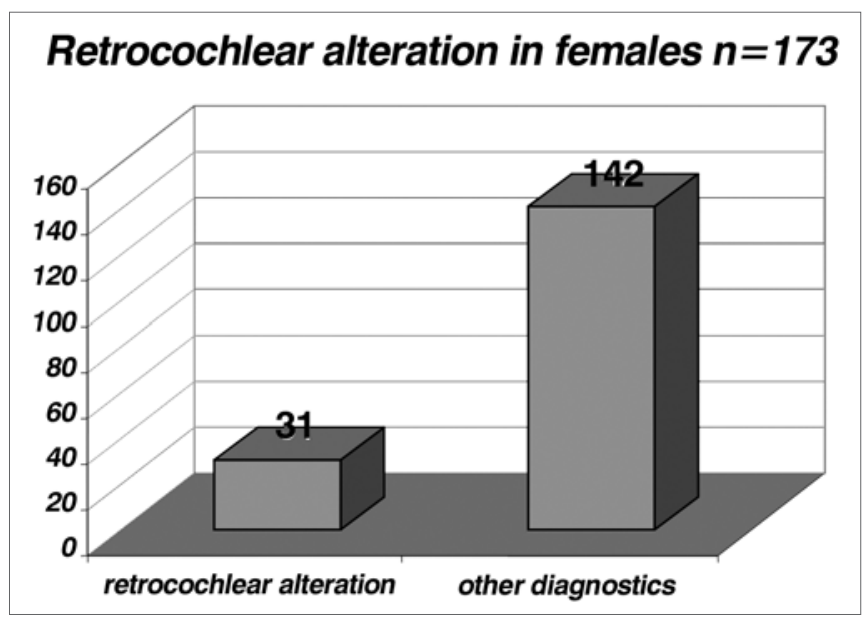

Graph 6. Incidence of female patients with retrocochlear alterations (index of 0.179 or $17.9 \%$ ).

\section{Retrocochlear alteration in males $n=230$}

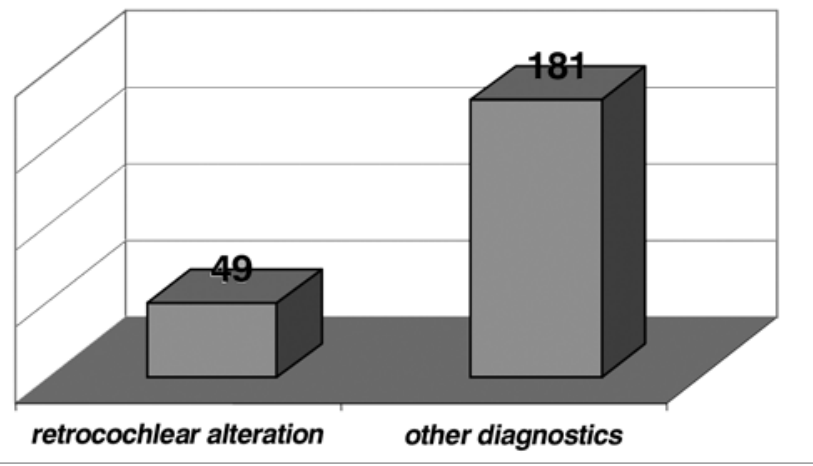

Graph 7. Incidence of male patients with retrocochlear alterations (index of 0.213 or $21.3 \%$ ).

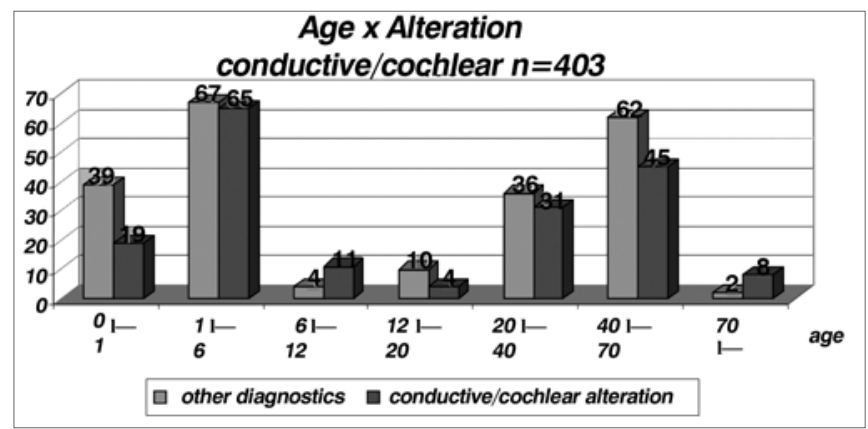

Graph 8. Distribution of patients with conductive or sensorineural alterations by age range in relation to other diagnostics $(n=403)$.

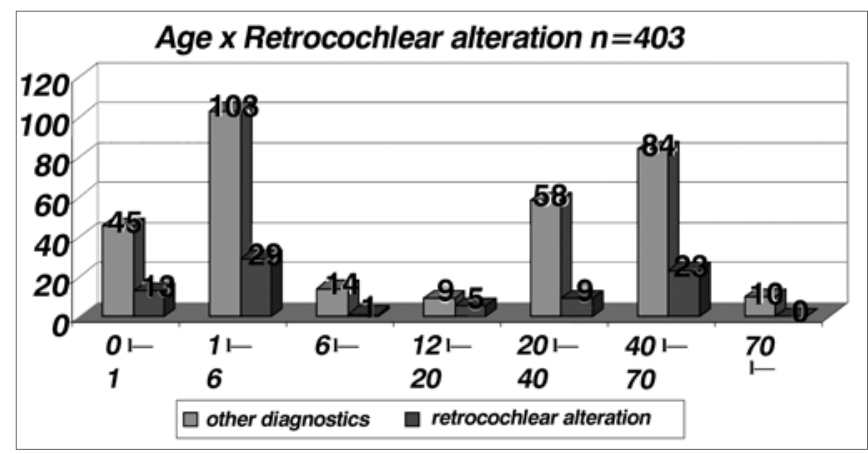

Graph 9. Distribution of patients with retrocochlear alterations per age range in relation to other diagnostics $(n=403)$.

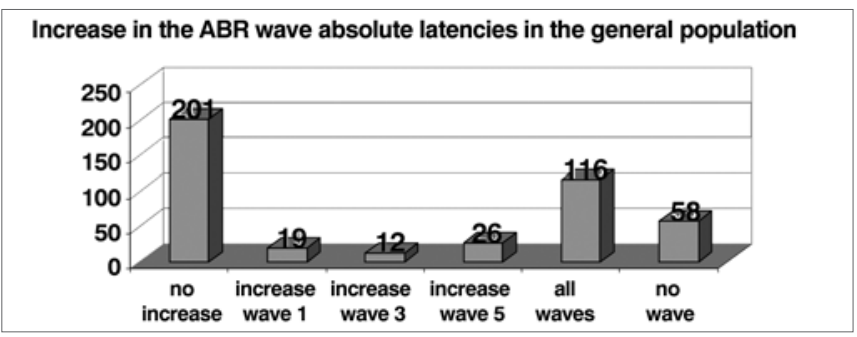

Graph 10. Increase in ABR wave absolute latency in the general population $(n=403)$.

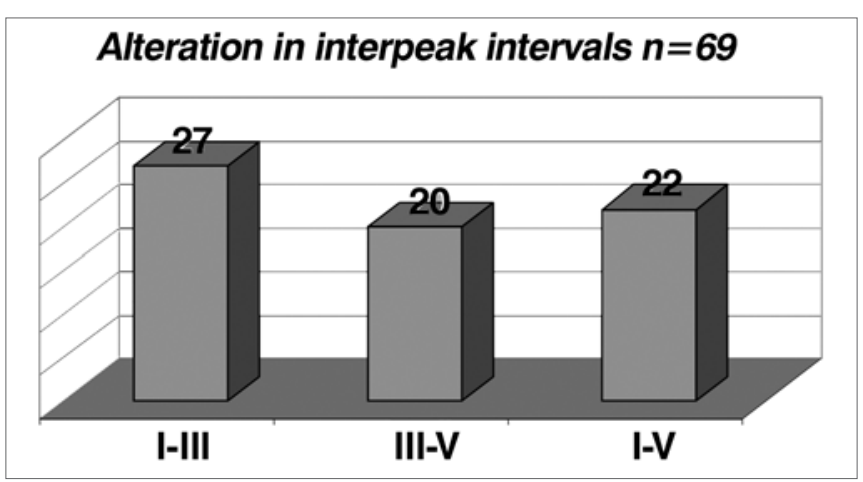

Graph 11. alterations in interpeak intervals $(n=69)$.

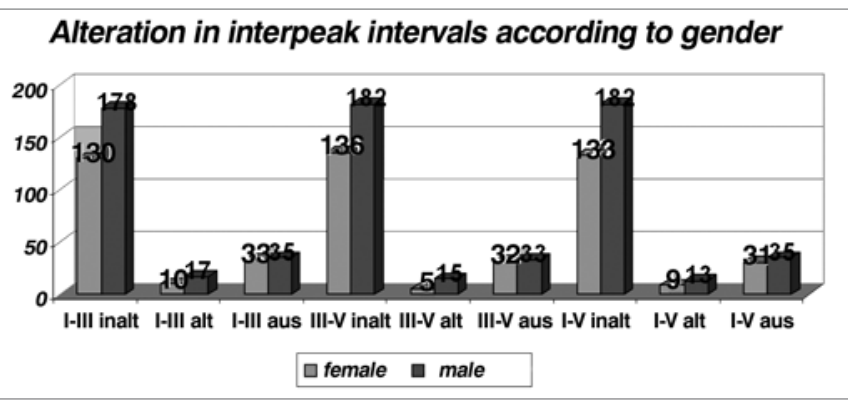

Graph 12. Alteration in interpeak intervals according to gender in the general population $(n=403)$. 


\section{CONCLUSIONS}

1. Brain Stem Audiometry (ABR) is a useful and objective test to determine the electrophysiological threshold determination, especially in children.

2. In adults, the brain stem auditory pathways evaluation for topodiagnosis is more prevalent.

3. The prevalence of conductive and/or cochlear findings was much higher than that of retrocochlear disorder.

4. There is significant difference in relation to the retrocochlear electrophysiological findings as far as gender is concerned, and it is more pronounced in males.

5. Children below 1 year of age bearing risk factors did not present higher incidences of cochlear, conductive and retrocochlear alterations in the ABR when compared to the general population. males.

6. The waves' absolute latencies were higher in

7. As to interpeak intervals, there was no gender difference and the I-III interval presented the higher incidence of alterations.

\section{REFERENCES}

1. Almeida ER, Butugan O, Silveira JAM. Potenciais evocados auditivos precoces ou de curta latência. In: Sih T, Caldas N(eds.): Otologia e Audiologia em Pediatria, 1a ed. Rio de Janeiro: Revinter; 1999. p. 216-23.
2. Figueiredo MS, Júnior NPC. Potenciais evocados auditivos de tronco encefálico (ABR). In: Figueiredo MS(ed.): Emissões otoacústicas e BERA, 1a ed. São José dos Campos: Pulso Editorial; 2003. p. 85-97.

3. Munhoz MSL, Silva MEG, Caovilla HH, Frazza MM, Ganança MM, Câmera JLS. Resposta auditiva de tronco encefálico. In: Munhoz MSL, Caovilla HH, Ganança MM (eds.): Audiologia Clínica, 1a ed. São Paulo: Atheneu; 2003. p. 191-220.

4. Junqueira CA, Frizzo ACF. Potenciais evocados auditivos de curta, média e longa latência. In: Aquino AMCM (ed.): Processamento auditivo-eletrofisiologia \& psicoacústica, 1a ed. São Paulo: Lovise; 2002. p. 63-86

5. Boone RT, Bower CM, Martin PF. Failed newborn hearing screens as presentation for otitis media with effusion in the newborn population. Int J Pediatr Otorhinolaryngol 2005;69:393-7.

6. Lieu JEC, Champion G. Prediction of auditory brainstem reflex screening referrals in high-risk infants. Laryngoscope 2006;116:261-7.

7. James ML, Husain AM. Brainstem auditory evoked potential monitoring: When is change in wave $\mathrm{V}$ significant? Neurology 2005;65(10):1551-5.

8. Cueva RA. Auditory brainstem response versus magnetic resonance imaging for the evaluation of asymmetric sensorineural hearing loss. Laryngoscope 2004;114:1686-92.

9. Joint Committee on Infant Hearing. Principles and guidelines for early hearing detection and intervention programs. Pediatrics Oct 2000;106(4):798-817.

10. Valete CM et al. Distribuição por sexo e faixa etária das aplicações clínicas da audiometria de tronco encefálico. Acta AWHO 2002;21(3,4)

11. Cruz Filho NA, Breuel MLF, Campilongo M. Presbiacusia. In: Campos CAH, Costa HOO (eds.): Tratado de Otorrinolaringologia. 1a ed. São Paulo: Ed. Roca; 2002. p. 186-92.

12. Flaviano FC, Leite RA, Matas CG. Audiometria de tronco encefálico em adultos audiologicamente normais: comparação das latências absolutas das ondas I,III,V, Interpicos I-III, III-V, I-V, amplitudes das ondas I, III, V e relação da amplitude V/I, obtidas em dois equipamentos diferentes. Acta AWHO 2002;21(2). 